INNOVATIVE UNIVERSITY PROGRAMS FOR TEACHING ABOUT DOMESTIC VIOLENCE

$$
2 / 12 / 2013
$$

Molly Dragiewicz

Queensland University of Technology

molly.dragiewicz@qut.edu.au

Angela R. Gover

University of Colorado at Denver

angela.gover@ucdenver.edu

Susan L. Miller

University of Delaware

slmiller@udel.edu

Jennifer Naccarelli

University of Delaware

jnacc@udel.edu

Barbara Paradiso

University of Colorado at Denver

Barbara.Paradiso@ucdenver.edu 
INNOVATIVE UNIVERSITY PROGRAMS FOR TEACHING ABOUT DV

\begin{abstract}
Universities and colleges across the country offer courses on domestic violence. A few programs have developed such academic opportunities even further, offering specializations, graduate certificates, and degrees concentrated on domestic violence. This paper introduces two innovative academic programs: the undergraduate Domestic Violence Prevention and Services Concentration and Minor at the University of Delaware and the graduate Program on Domestic Violence at the University of Colorado Denver. The authors introduce these programs with a view to informing and inspiring others who might be interested in establishing similar curricula at their own institutions.
\end{abstract}

Keywords: Domestic violence; violence against women; women’s studies; university 
INNOVATIVE UNIVERSITY PROGRAMS FOR TEACHING ABOUT DV

\section{INNOVATIVE UNIVERSITY PROGRAMS FOR TEACHING ABOUT DOMESTIC}

\section{VIOLENCE}

This special issue provides an opportunity to share information about the academic study of domestic violence (DV). This snapshot highlights two academic programs: the undergraduate Domestic Violence Prevention and Services Concentration and Minor (DVPS) at the University of Delaware, and the graduate Program on Domestic Violence (PDV) at the University of Colorado Denver. Both of these programs emphasize praxis through the integration of community work on DV with university level education.

\section{THE DOMESTIC VIOLENCE PREVENTION AND SERVICES CONCENTRATION}

\section{AND MINOR AT THE UNIVERSITY OF DELAWARE}

The DVPS program offers an undergraduate concentration and minor. The program is the result of collaboration between the Delaware Coalition Against Domestic Violence (DCADV) and the Department of Women and Gender Studies, with funding provided by a grant from the Verizon Foundation, Inc. This program is rooted in feminist principles and designed to focus on the needs of survivors of abuse and the organizations that assist them. The program provides career skills for after graduation while nurturing the next generation of anti-violence advocates. Key components of this program include a curriculum coordinated with state certification requirements and a funded summer practicum.

Course requirements were developed in coordination with DCADV's program for Domestic Violence Specialist Certification so that students who complete the DVPS concentration or minor fulfill a significant portion of the education and direct service requirements for certification. The program is interdisciplinary and draws its five core teaching 
INNOVATIVE UNIVERSITY PROGRAMS FOR TEACHING ABOUT DV

faculty from Women’s Studies, Criminal Justice, Sociology, and Human Development and Family Studies.

\section{DVPS Program Requirements}

The DVPS concentration is a competitive program open to Women's Studies majors at the University of Delaware. The program currently accepts six concentration students per year, and students receive a stipend to fund a required ten week summer practicum. The stipend ensures that students from all socio-economic backgrounds have the freedom to participate. Students in the DVPS concentration complete the required courses for the Women's Studies major, four specific DV courses, and one of four elective DV courses. Concentration students also complete a ten week summer practicum which involves 300 hours of direct service through an approved DV service provider.

The practicum is a key feature of the DVPS concentration providing an opportunity for students to apply coursework to the field through direct service. Direct service is defined as activities responding to the needs of victims, perpetrators, children, and/or other family members specific to their DV experience, for example via such activities as case management, counselling, intake and assessment, safety planning, and advocacy. Practicum students are hosted by participating agencies across the state. DVPS concentration students generally graduate with 500 hours of direct service experience, a significant portion of the 2000 service hours required to apply to be a Certified Domestic Violence Specialist through the DCADV .

The DVPS program offers a minor in addition to the DV concentration. Unlike the concentration, a competitive program open to only Women's Studies majors, the minor is available to all students within the university. The minor requires the completion of Introduction to Women's Studies, three specific DV courses, and two from four DV elective courses. DVPS 
INNOVATIVE UNIVERSITY PROGRAMS FOR TEACHING ABOUT DV

minor students generally graduate with approximately 200 hours of direct service experience via internship courses.

\section{THE PROGRAM ON DOMESTIC VIOLENCE AT THE UNIVERSITY OF COLORADO DENVER}

The PDV is a graduate level program designed to meet two disparate needs: helping DV service workers acquire leadership skills to aid professional advancement and providing education for management staff hired into DV organizations without pertinent anti-violence experience. The PDV was planned collaboratively with The Sunshine Lady Foundation Inc. which provided support for program development. Key features of this program include its hybrid format combining online work with intensive cohort sessions on campus and a variety of specializations and degrees built around the core courses.

The first cohort entered the program in the fall of 2000. Today, students can complete a concentration in the program on Domestic Violence Management and Policy Development in the Master of Public Administration degree (MPA PDV) or the Master of Criminal Justice degree (MCJ PDV). The PDV also offers two stand-alone certificates: the Certificate in Interpersonal Violence and Health Care and the Certificate in Domestic Violence Studies.

\section{PDV Requirements}

Students in the program are admitted biannually in cohorts, and take four courses in intensive on-campus sessions. In addition to the course work, ten to fifteen hours of training per semester is provided over the two year program of study to promote skill and leadership development explicitly focused on DV. The DV intensive courses are taught by one university faculty member assigned to the program or outside instructors and practitioners. National experts selected with input from the cohort visit the program and participate in the intensive sessions. 
INNOVATIVE UNIVERSITY PROGRAMS FOR TEACHING ABOUT DV

Students can take the four intensive DV concentration courses as a standalone Certificate in Domestic Violence Studies. In addition to the four required DV courses, PDV students complete additional courses specific to their enrolment in the MPA or MCJ track, an internship, and a capstone project or thesis. In each area, the program maintains a focus on leadership development. While the specific skills in different fields vary, the goal remains the same: to increase the sensitivity, knowledge, and capacity of systems and communities to effectively prevent and respond to DV.

\section{BENEFITS OF UNIVERSITY BASED DOMESTIC VIOLENCE PROGRAMS}

We surveyed instructors and administrators associated with the PDV and DVPS in order to learn about their perceptions of the programs. We received feedback from four tenured faculty members, three instructors, and five administrators. The administrators and instructors involved with these programs described a variety of benefits. Instructors in both programs enjoyed teaching highly engaged students.

By having the PDV we are attracting the most academically qualified students in the fields of public affairs and criminal justice for graduate studies. (Colorado instructor A) Faculty also enjoyed teaching and learning from the diverse group of students attracted to the DV courses.

Meeting the future leadership of the movements against domestic and sexual violence [is a benefit of the program]. ... They have an enormous amount to teach me. (Colorado instructor C)

Those involved in the programs appreciated the opportunity to connect course content with real world needs. 
INNOVATIVE UNIVERSITY PROGRAMS FOR TEACHING ABOUT DV

This program gives students the opportunity to try on a career while they are still in college, which better prepares them for the workplace later. It also puts them at an advantage when they want to get a job - they have practical experience, and know how to dress and carry themselves on job interviews and in professional situations. (Delaware instructor C)

Instructors remarked that making the connection between course content and anti-violence practices explicitly transformed student learning.

Having the program makes teaching about these issues real to students, both those in and not in the program. I was teaching this particular class before the DV program was implemented, and having students who are focused on this area and have additional background has led to more student discussion and student-generated examples. (Delaware instructor B) Students reinforced these perceptions.

[Students] reported that the experience they gained during their internships was invaluable as they were able to apply knowledge gained in the classroom to the real world. (Delaware instructor D)

Instructors and administrators described benefits to the university and department including: increased visibility; enhanced collaboration across programs; and strengthened relationships with community organizations. These benefits align with university mandates around enrolment, town and gown relations, publicity, student employment rates, interdisciplinary research, and collaboration with external funders.

The DVPS has program has attracted a number of majors to our department, students who are interested in violence policy and prevention but who might not have otherwise 
INNOVATIVE UNIVERSITY PROGRAMS FOR TEACHING ABOUT DV

considered a major in women's studies. The DVPS program has increased our departmental visibility both within and outside of the university. (Delaware program director)

Those involved in the programs noted the ways that the programs build community connections. In Delaware, students provide 3,200 hours of direct service per year and have collected 2,700 cell phones for emergency use, raising nearly \$5,000 for DCADV. In Colorado, students complete capstone projects that fulfill a community research need. One cohort of students identified a need for address confidentiality for DV victims. They identified legislative sponsors, drafted a bill, and testified before the legislature. The bill passed, and Colorado now has one of the most comprehensive address confidentiality programs in the country. Instructors and administrators appreciated such connections to the community.

I am a member of the DCADV and I regularly hear praise about the program at events and gratitude about the resources we are creating through our students' efforts. (Delaware instructor A)

Overall, instructors saw intellectual and professional benefits from student involvement in the programs. Both programs fostered to the benefit of the university and the students.

\section{CHALLENGES FOR UNIVERSITY BASED DOMESTIC VIOLENCE PROGRAMS}

Alongside the benefits of these programs are challenges. The same diversity of experience that makes courses on DV rewarding for students and faculty can make teaching and learning around the issue tricky. Faculty members in these courses are called upon to address classroom climate in ways not required in other types of courses.

One challenge associated with teaching the domestic violence courses is the need for student survivors to be at a point in their own recovery where they can be as objective as 
INNOVATIVE UNIVERSITY PROGRAMS FOR TEACHING ABOUT DV

possible about the academic subject matter of their domestic violence classes. (Colorado instructor A)

Myths and misconceptions about the problem persist in the face of decades of consciousnessraising about DV.

Since my course attracts many different students, there are always a number of them who come to the class knowing very little about DV and they are often very accepting of myths heard in the news. (Delaware instructor C)

Another challenge identified was funding.

The Verizon Foundation provided funding for our implementation and student stipends, with the conclusion of our grant term approaching we are in the process of identifying agencies willing to support students who provide direct services. (Delaware program director)

There are also academic challenges. Domestic violence is a complicated issue to cover in a limited time. There are also gaps in the research literature that can be challenging.

I teach Domestic Violence and Social Change, which is a big topic. It's sometimes a challenge to quantify such a large issue. ... In this course, we're also linking DV to other forms of oppression, which is critical, but can be overwhelming at times. (Colorado instructor B)

In addition, the emphasis on praxis is controversial. Some scholars believe that science and advocacy don’t mix. Program Directors are aware of a:

clash in values between the goals of the school and/or University and the program. Those things that help to define excellence in an academic setting (e.g. high GPA, high GREs) may prevent access to the program for the very students the program was designed to 
INNOVATIVE UNIVERSITY PROGRAMS FOR TEACHING ABOUT DV

serve and represent strong potential for future leadership in the domestic violence movement (e.g. committed and passionate survivors, women of color, etc.). (Colorado Program Director)

Teaching about DV is pedagogically challenging for the same reasons it is rewarding. The issue brings together powerful experiences and academic content in a way that is unusual in academia. Additional challenges arise from the lack of financial support for DV programs. Colorado relies on adjunct faculty to teach the majority of the courses in the DVP. Only one tenured faculty member is currently assigned to the program. These structural factors present sustainability issues that may necessitate changes in the future.

\section{FUTURE DIRECTIONS FOR UNIVERSITY BASED DOMESTIC VIOLENCE EDUCATION}

The directors of these programs recommend the following to others thinking of developing a university based program on DV:

- Develop and formalize a collaborative relationship with community organizations to ensure that the content and values of the program match community needs.

- Work with a team of practitioners to develop and implement the program.

- Identify and put in writing key values, concepts, structural needs before any negotiations begin.

- $\quad$ Engage and seek administrative buy-in at all levels of the university.

- Recognize that the program will not likely attract large numbers of students, at least at first, and plan accordingly. 
INNOVATIVE UNIVERSITY PROGRAMS FOR TEACHING ABOUT DV

- Build and maintain a broad base of practitioners, professors, and administrators internal and external to the university to ensure a supportive and knowledgeable advisory board for program.

Program Directors emphasized that without a foundation in the feminist values of the battered women’s movement, it is easy for programs to stray from social justice priorities within an environment that does not always understand this kind of work.

This review of two innovative programs raises numerous questions for further study. It would be useful for future research to provide a comprehensive overview of available programs. Other studies could assess the curricular content of DV programs. Additional research could track graduates’ career paths. Likewise, scholars could survey DV organizations in order to measure the impact of programs on the practice community.

On a theoretical level, this snapshot does not engage with intense debates among antiviolence advocates and scholars about the increasing assimilation of anti-violence organizations into the machinery of the neoliberal state (Beres, Crow, \& Gottell, 2008; Markowitz \& Tice, 2002; Reinelt, 1995; Richie, 2000; Wies, 2008). Colorado and Delaware have different approaches to certification for advocates based on local perspectives about the best way to address violence. As the DV movement has developed into an institutionalized sector for research and practice, there has been much reflection about the political choices made by organizations doing anti-violence work. Both of these programs attempt to address race and class through course content and funding schemes. However, the work to examine the contradictions between revolutionary models for social change to end violence and oppression and service provision in the non-profit sector is just beginning (INCITE!, 2009). 
INNOVATIVE UNIVERSITY PROGRAMS FOR TEACHING ABOUT DV

Nonetheless, university based programs offer a valuable experience for those involved. As DCADV director Carol Post put it, "we hope this program continues to grow and becomes a model for programs based on academic/community partnerships at the undergraduate level around the country.” As the quotations from those involved in both programs show, university based programs can be a rewarding experience for students, faculty, staff, and community organizations. The graduates of these programs acquire specialized information and skills that bridge theory and practice. They can apply this knowledge to future leadership in the antiviolence movement or carry it with them to their other endeavors. 
INNOVATIVE UNIVERSITY PROGRAMS FOR TEACHING ABOUT DV

\section{REFERENCES}

Beres, M. A., Crow, B., \& Gotell, L. (2008). The perils of institutionalization in neoliberal times:

Results of a national survey of Canadian sexual assault and rape crisis centres. Canadian Journal of Sociology, 34(1), 135-164.

Delaware Coalition Against Domestic Violence. (n.d.). Training and certification. Retrieved September 17, 2012, from http://www.dcadv.org/training-and-certification\#certification

INCITE! Women of Color Against Violence (Ed.). (2009). The revolution will not be funded: Beyond the non-profit industrial complex. Boston: South End Press.

Markowitz, L., \& Tice, K. W. (2002). Paradoxes of professionalization: Parallel dilemmas in women’s organizations in the Americas. Gender and Society, 16(6), 941-958.

Reinelt, C. (1995). Moving onto the terrain of the state: The battered women's movement and the politics of engagement. In M. M. Feree \& P. Y. Martin (Eds.), Feminist organizations: Harvest of the new women's movement (pp. 84-104). Philadelphia, PA: Temple University Press.

Richie, B. E. (2000). A Black feminist reflection on the anti-violence movement. Signs, 25(4), 11331137.

Wies, J.R. (2008). Professionalizing human services: A case of domestic violence shelter advocates. Human Organization, 67(2), 221-233. 
INNOVATIVE UNIVERSITY PROGRAMS FOR TEACHING ABOUT DV

\section{AUTHOR BIOS}

Molly Dragiewicz is Associate Professor of Criminology in the Faculty of Social Science and Humanities at the University of Ontario Institute of Technology in Canada and Visiting Fellow in the School of Justice, Faculty of Law at Queensland University of Technology in Australia. She is author of Equality with a vengeance: Men's rights groups, battered women, and antifeminist backlash.

Angela R. Gover is Professor of Criminology and Criminal Justice in the School of Public Affairs at the University of Colorado Denver. Her research focuses on gender and crime, violence against women, and victimization.

Susan L. Miller is Professor of Sociology and Criminal Justice at the University of Delaware. Her research interests are gender and crime, violence against women, victimology, and restorative justice. Her most recent book, After the Crime: The Power of Restorative Justice Dialogues between Victims and Violent Offenders (New York University Press, 2011) received the Best Book Award from the Academy of Criminal Justice Sciences in 2012.

Jennifer Naccarelli is Associate Chair and Assistant Professor of Women and Gender Studies at the University of Delaware. Additionally, she is the director of the Domestic Violence Prevention and Services Program. She has a PhD in Women's Studies in Religion from the Claremont Graduate University.

Barbara Paradiso is Director of the Center on Domestic Violence at the School of Public Affairs, University of Colorado Denver (CU Denver). Barbara has worked on behalf of battered women for more than thirty years as an advocate, administrator and activist. She has participated in boards and commissions including the Colorado Coalition Against Domestic Violence, Boulder Shelter for the Homeless, the YWCA of Boulder County and the National Coalition Against Domestic Violence. Ms. Paradiso received her Master's degree in Public Administration from the University of Colorado Denver. 